\title{
Efficacy of Enzyme Replacement Therapy on the range of motion of the upper and lower extremities in 16 Polish patients with mucopolysaccharidosis type II: A long-term follow-up study
}

\author{
Jolanta Marucha, Patryk Lipiński $\bowtie$ and Anna Tylki-Szymańska \\ Department of Pediatrics, Nutrition and Metabolic Diseases, The Children's Memorial Health Institute, Warsaw, Poland
}

Background: Enzyme replacement therapy (ERT) with idursulfase is available for patients with mucopolysaccharidosis (MPS) type II, and improvements in certain somatic signs and symptoms have been reported. The aim of the study was to assess the effectiveness of ERT with idursulfase (Elaprase ${ }^{\circledR}$ ) on the passive joint range of motion (JROM) in the upper and lower extremities of patients with MPS II. Methods: The study included 16 Polish patients diagnosed with MPS II and followed in our Institute in the years 2009-2016. The study group was divided for groups of neuronopathic (group 1, $n=12$ ) and non-neuronopathic (group 2, $n=4$ ) patients. A passive JROM was measured with a goniometer by one physiotherapist, while in group 1 it was assessed at baseline and after both short-term (52 weeks) and long-term (mean 230 weeks, range: 108-332 weeks) ERT. In group 2 , it was assessed at baseline and after short-term ERT (68-85 weeks, no data for long-term ERT). Results: In group 1, after 52 weeks of ERT, we observed some improvement of passive ROM in wrist flexion (5/12 patients), shoulder abduction and wrist extension (3/12 patients), shoulder flexion, elbow and knee extension (2/12 patients). After long-term ERT (mean 230 weeks), the improvement in JROM was observed only in 2 patients. There was no improvement in the shoulder abduction, elbow flexion and extension, hip and knee extension. In group 2, the improvement in passive ROM was observed in several joints: shoulder flexion, wrist flexion and extension improved (2/4 patients) and shoulder abduction (1/4 patients). Conclusion: ERT is of low efficacy on correcting the range of motion of joints in MPS II patients.

Keywords: mucopolysaccharidosis type Il; enzyme replacement therapy; range of motion; bone and joint disease

Received: 08 December, 2021; revised: 07 January, 2022; accepted: 07 January, 2022; available on-line: 28 February, 2022

$\bowtie$ e-mail: p.lipinski@ipczd.pl

Abbreviations: ERT, enzyme replacement therapy; I2S, iduronate2-sulfatase; JROM, joint range of motion; MPS, mucopolysaccharidosis

\section{INTRODUCTION}

Mucopolysaccharidosis (MPS) type II, also known as Hunter syndrome (\# 309900), is an X-linked lysosomal storage disease characterized by a multi-systemic involvement and progressive clinical course (Tylki-Szymańska et al., 2014; Scarpa et al., 2011). MPS II is caused by hemizygous pathogenic variants of the IDS gene resulting in the deficient activity of the enzyme, iduronate2-sulfatase (I2S, EC 3.1.6.13), and characterized by the accumulation of glycosaminoglycans (GAGs) (Tylki-
Szymańska et al., 2014; Scarpa et al., 2011). The impactful difference in disease progression and clinical outcome is attributable to the presence or absence of primary neuronopathic disease (Beck et al., 2010; Shapiro et al., 2016). A degenerative joint and bone disease is due to the lack of skeletal remodelling, disordered endochondral and intramembranous ossification, disruption of normal elastogenesis, and the deposition of GAGs in muscles, tendons, and ligaments (Hinek et al., 2000; Simonaro et al., 2008). The severity of motor compromise is caused by deposition of GAGs in the soft tissue of core and periphery structures (cervical compression, hydrocephalus, carpal tunnel syndrome), and often determines other functional abilities.

In 2006, Enzyme Replacement Therapy (ERT) with recombinant human I2S (Elaprase ${ }^{\circledR}$, Shire Human Genetic Therapies, Inc., Cambridge, MA, USA) was approved for the treatment of Hunter syndrome addressing the underlying pathophysiology by delivering sufficient I2S to reverse and prevent GAG accumulation (Muenzer et al., 2006; Muenzer et al., 2007; Muenzer et al., 2011).

The aim of the study was to assess the effectiveness of ERT with idursulfase (Elaprase ${ }^{\circledR}$ ) on the passive joint range of motion (JROM) in the upper and lower extremities of patients with MPS II diagnosed and treated in one centre in the years 2009-2016.

\section{PATIENTS AND METHODS}

\section{Patients}

The study included 16 Polish patients (15 male and one female) diagnosed with MPS II and followed in one centre (Children's Memorial Health Institute, CMHI, Warsaw, Poland) during the years 2009-2016. All the study patients received ERT with recombinant human I2S (Elaprase ${ }^{\circledR}$ ), $0.5 \mathrm{mg} / \mathrm{kg}$ weekly intravenously. Individual patient's characteristics is presented in Table 1.

\section{Methods}

The diagnosis of MPS II was confirmed by the demonstration of reduced iduronate-2-sulfatase activity in the serum or peripheral blood leukocytes. Sequence analysis of the IDS gene was performed by targeted gene sequencing.

The study group was divided for groups of neuronopathic (group 1, n=12) and non-neuronopathic (group 2, $n=4)$ patients, see Table 1 . The passive joint range of motion (JROM) was measured in degrees with a goniometer and was assessed by one physiotherapist (JM) using the International Method of Measuring and Re- 
Table 1. Study patients' characteristics.

\begin{tabular}{|c|c|c|c|c|c|c|}
\hline $\begin{array}{l}\text { Patient } \\
\text { No }\end{array}$ & $\begin{array}{l}\text { Age } \\
\text { at diagnosis }\end{array}$ & $\begin{array}{l}\text { Age } \\
\text { at the start } \\
\text { of ERT }\end{array}$ & $\begin{array}{l}\text { Duration } \\
\text { of treatment } \\
\text { (weeks) } \\
\text { short-/long-term ERT }\end{array}$ & Molecular analysis & MPS phenotype & $\begin{array}{l}\text { Family } \\
\text { background }\end{array}$ \\
\hline \multicolumn{7}{|l|}{ Group 1} \\
\hline 01 & $1 \mathrm{mo}$ & $3 \mathrm{mo}$ & $52 / 332$ & c. $1568 A>G$, p.Tyr523Cys & $\begin{array}{l}\text { Neuronopathic } \\
\text { (severe) }\end{array}$ & Sibling \\
\hline $02^{*}$ & 5 y & $10 y$ & $52 / 208$ & $\begin{array}{l}\text { c. } 1568 A>\text { G, p.Tyr523Cys/ } \\
\text { c. } 1568 A>\text { G, p.Tyr523Cys }\end{array}$ & $\begin{array}{l}\text { Neuronopathic } \\
\text { (severe) }\end{array}$ & Sibling \\
\hline 03 & $1.5 \mathrm{y}$ & $3 y$ & $52 / 234$ & c.908_909del, p.Ser303fs & $\begin{array}{l}\text { Neuronopathic } \\
\text { (severe) }\end{array}$ & $\begin{array}{l}\text { maternal first } \\
\text { cousin }\end{array}$ \\
\hline 04 & $2 y$ & $3 y$ & $52 / 208$ & c.908_909del, p.Ser303fs & $\begin{array}{l}\text { Neuronopathic } \\
\text { (severe) }\end{array}$ & $\begin{array}{l}\text { maternal first } \\
\text { cousin }\end{array}$ \\
\hline 05 & 1 y 3 mo & $3 y$ & $52 / 312$ & c.998C>T, p.Ser333Leu & $\begin{array}{l}\text { Neuronopathic } \\
\text { (severe) }\end{array}$ & None \\
\hline 06 & 3 y 4 mo & $4 y$ & $52 / 208$ & c.998C>T, p.Ser333Leu & $\begin{array}{l}\text { Neuronopathic } \\
\text { (severe) }\end{array}$ & None \\
\hline 07 & $3 y$ & $3 y$ & $52 / 260$ & c.998C>T, p.Ser333Leu & $\begin{array}{l}\text { Neuronopathic } \\
\text { (severe) }\end{array}$ & None \\
\hline 08 & 2 y 10 mo & $3 y$ & $52 / 216$ & c.1007G>A, p.Gly336Val & $\begin{array}{l}\text { Neuronopathic } \\
\text { (severe) }\end{array}$ & None \\
\hline 09 & 2 y 3 mo & $3 y$ & $52 / 208$ & n.a. & $\begin{array}{l}\text { Neuronopathic } \\
\text { (severe) }\end{array}$ & None \\
\hline 10 & 3.5 y & 4 y 4 mo & $52 / 260$ & c.1239_1240insCT, p.Ala414fs & $\begin{array}{l}\text { Neuronopathic } \\
\text { (severe) }\end{array}$ & None \\
\hline 11 & $4 y$ & 11 y 8 mo & $52 / 208$ & c.879G >A, p.Gln293GIn & $\begin{array}{l}\text { Neuronopathic } \\
\text { (severe) }\end{array}$ & None \\
\hline 12 & $3.5 \mathrm{y}$ & 11 y 8 mo & $52 / 108$ & c.1478G>C, p.Arg493Pro & $\begin{array}{l}\text { Neuronopathic } \\
\text { (severe) }\end{array}$ & None \\
\hline \multicolumn{7}{|l|}{ Group 2} \\
\hline 13 & $8.5 \mathrm{y}$ & 12.5 y & 82 & c.181T>C, p.Cys61Gly & $\begin{array}{l}\text { Non-Neuronopa- } \\
\text { thic }\end{array}$ & None \\
\hline 14 & $6.5 \mathrm{y}$ & 12 y 9 mo & 85 & c.1030G>A, p.E344* & $\begin{array}{l}\text { Non-Neuronopa- } \\
\text { thic }\end{array}$ & None \\
\hline 15 & 1 y 3 mo & $26 y$ & 68 & c. $1034 \mathrm{G}>\mathrm{T}, \mathrm{p} . \operatorname{Trp} 345 \mathrm{Ser}$ & $\begin{array}{l}\text { Non-Neuronopa- } \\
\text { thic }\end{array}$ & $\begin{array}{l}\text { maternal first } \\
\text { cousin }\end{array}$ \\
\hline 16 & $5 y$ & $28 y$ & 68 & c.1034G>T, p.Trp345Ser & $\begin{array}{l}\text { Non-Neuronopa- } \\
\text { thic }\end{array}$ & $\begin{array}{l}\text { maternal first } \\
\text { cousin }\end{array}$ \\
\hline
\end{tabular}

Abbreviations: y, years; mo, months; n.a., not analyzed; "female.

cording Joint Motion (SFTR; sagittal, frontal, transverse, rotation) (Gerhardt et al., 2001; Marucha et al., 2012). In patients from group 1, passive JROM was assessed at baseline and over the course of short-term (52 weeks) and long-term (mean 230 weeks, range: 108-332 weeks) ERT. In patients from group 2, passive JROM was assessed at baseline and over the course of short-term ERT (68-85 weeks, no data for long-term ERT).

The Sign test and $p$-value were used to assess the efficacy of ERT with idursulfase on the passive JROM. Ethical approval was obtained from the Children's Memorial Health Institute Bioethical Committee, Warsaw, Poland.

\section{RESULTS}

\section{Study's population}

The mean patient age at MPS II diagnosis was 3 years and 4 months (age range: 1 month -8.5 years). One patient (Patient 01) was diagnosed through family screening (his older sister - Patient 02 - had a diagnosis of MPS II). Twelve out of $16(75 \%)$ patients presented with a neuronopathic (severe) phenotype, while 4 others showed the attenuated phenotype.

The mean age at ERT initiation was 8 years and 8 months (age range: 3 months - 28 years).

\section{Range of motion}

Group 1 - neuronopathic (severe) phenotype, $\mathrm{n}=12$

After the short-term ERT, a passive ROM of the wrist flexion improved in $5(42 \%)$ patients, while of shoulder abduction and wrist extension improved in 3 $(25 \%)$ patients, and of shoulder flexion as well as elbow and knee extension improved in 1 (8\%) patient (Table 2 and Fig. 1). In four (33\%) patients there was observed an improvement in passive ROM of at least two joints. There was no improvement in the hip extension.

After long-term ERT, there was observed an improvement of a passive ROM in two $(16 \%)$ patients. 
Table 2. Efficacy of short-term and long-term ERT on passive JROM of the upper and lower extremities in group 1.

JROM values (in degrees) for each patient were presented in one raw as following: at baseline, after short-term ERT, after long-term ERT. An increase in passive ROM of at least $10^{\circ}$ was considered an improvement and indicated by bold font.

\begin{tabular}{|c|c|c|c|c|c|c|c|c|}
\hline $\begin{array}{l}\text { Movement } \\
\text { in degrees } \\
\text { Passive } \\
\text { ROM } \\
\text { (normal) }\end{array}$ & $\begin{array}{l}\text { Shoulder } \\
\text { flexion } \\
\left({ }^{\circ}\right) \\
180\end{array}$ & $\begin{array}{l}\text { Shoulder } \\
\text { abduction } \\
\left({ }^{\circ}\right) \\
180\end{array}$ & $\begin{array}{l}\text { Elbow } \\
\text { flexion } \\
\left({ }^{\circ}\right) \\
155\end{array}$ & $\begin{array}{l}\text { Elbow } \\
\text { extension } \\
\left({ }^{\circ}\right) \\
0\end{array}$ & $\begin{array}{l}\text { Wrist } \\
\text { flexion } \\
\left({ }^{\circ}\right) \\
90\end{array}$ & $\begin{array}{l}\text { Wrist } \\
\text { extension } \\
\left({ }^{\circ}\right) \\
80\end{array}$ & $\begin{array}{l}\text { Hip } \\
\text { extension } \\
\left({ }^{\circ}\right) \\
20\end{array}$ & $\begin{array}{l}\text { Knee } \\
\text { extension } \\
\left({ }^{\circ}\right) \\
0\end{array}$ \\
\hline \multicolumn{9}{|l|}{ Patient no } \\
\hline 01 & $180 / 170 / 140$ & $180 / 160 / 130$ & $155 / 155 / 155$ & $0 / 0 / 0$ & $90 / 90 / 80$ & $80 / 80 / 60$ & $20 / 20 / 20$ & $0 / 0 / 0$ \\
\hline 02 & $120 / 120 / 120$ & $100 / 90 / 90$ & $150 / 140 / 150$ & $-40 /-30 /-45$ & $40 / 50 / 30$ & $20 / 20 / 10$ & $0 / 0 /-20$ & $-10 / 0 /-20$ \\
\hline 03 & $170 / 160 / 130$ & $160 / 150 / 80$ & $150 / 150 / 140$ & $0 /-5 /-30$ & $80 / 40 / 40$ & $60 / 20 / 10$ & $20 / 0 / 20$ & $-10 / 0 / 0$ \\
\hline 04 & $150 / 140 / 130$ & $150 / 130 / 90$ & $150 / 150 / 130$ & $-10 /-20 /-45$ & $70 / 50 / 60$ & $60 / 50 / 40$ & $20 / 20 /-40$ & $-5 /-10 /-30$ \\
\hline 05 & $150 / 170 / 110$ & $130 / \mathbf{1 5 0} / 90$ & $150 / 150 / 100$ & $-10 / 0 /-30$ & $80 / 90 / 40$ & $70 / 80 / 10$ & $20 / 0 /-20$ & $-5 /-20 /-20$ \\
\hline 06 & $150 / 140 / 130$ & $140 / 140 / 100$ & $120 / \mathbf{1 5 0} / \mathbf{1 3 0}$ & $0 / 0 /-30$ & $90 / 90 / 70$ & $80 / 80 / 20$ & $0 / 0 /-20$ & $-10 /-10 /-30$ \\
\hline 07 & $170 / 170 / 160$ & $170 / 170 / 140$ & $155 / 155 / 125$ & $0 / 0 /-30$ & $90 / 90 / 90$ & $80 / 80 / 30$ & $0 / 0 / 0$ & $-20 /-20 /-30$ \\
\hline 08 & $150 / 130 / 130$ & $130 / 120 / 110$ & $155 / 150 / 130$ & $-20 /-20 /-20$ & $90 / 90 / 90$ & $80 / 70 / 30$ & $20 / 20 / 0$ & $0 / 0 /-10$ \\
\hline 09 & $140 / 140 / 130$ & $130 / \mathbf{1 4 0} / 110$ & $150 / 150 / 130$ & $-10 /-20 /-30$ & $80 / 90 / 80$ & $70 / \mathbf{8 0} / 40$ & $20 / 20 / 0$ & $0 / 0 /-10$ \\
\hline 10 & $140 / \mathbf{1 5 0} / 120$ & 140/150/110 & $150 / 150 / 130$ & $-20 /-20 /-30$ & $70 / \mathbf{8 0} / \mathbf{8 0}$ & $50 / 60 / 40$ & $20 / 0 / 0$ & $-20 /-20 /-15$ \\
\hline 11 & $130 / 120 / 140$ & $130 / 110 / 120$ & $150 / 120 / 130$ & $-40 /-50 /-40$ & $40 / 20 / 50$ & 20/10/30 & $0 / 0 / 0$ & $0 / 0 /-20$ \\
\hline 12 & $120 / 110 / 110$ & $120 / 90 / 90$ & $150 / 120 / 120$ & $-40 /-50 /-50$ & $30 / 60 / 10$ & $20 / 0 / 0$ & $0 / 0 /-30$ & $-10 /-20 /-30$ \\
\hline Mean & $\begin{array}{l}147.5 / 143.3 / \\
129.2\end{array}$ & $\begin{array}{l}140.0 / 134.2 / \\
105.0\end{array}$ & $\begin{array}{l}148.8 / 145.0 / \\
130.8\end{array}$ & $\begin{array}{l}-15.8 /-17.9 / \\
-31.7\end{array}$ & $\begin{array}{l}70.8 / 70.0 / \\
60.0\end{array}$ & $\begin{array}{l}57.5 / 52.5 / \\
26.7\end{array}$ & $\begin{array}{l}11.7 / 6.7 / \\
-7.5\end{array}$ & $\begin{array}{l}-7.5 /-8.3 / \\
-17.9\end{array}$ \\
\hline S.D. & $\begin{array}{l}19.1 / 21.0 / \\
13.8\end{array}$ & $22.2 / 25.4 / 18.3$ & $\begin{array}{l}9.3 / 12.2 / \\
14.0\end{array}$ & $\begin{array}{l}16.2 / 18.3 / \\
13.2\end{array}$ & $\begin{array}{l}21.9 / 24.9 / \\
25.9\end{array}$ & $\begin{array}{l}24.5 / 31.4 / \\
17.2\end{array}$ & $\begin{array}{l}10.3 / 9.8 / \\
18.6\end{array}$ & 7.2/9.4/11.2 \\
\hline *Sign test & 1.845 & 0.948 & 0.894 & 1.061 & 0.667 & 0.667 & 0.154 & 0.405 \\
\hline${ }^{*} p$-value & $\begin{array}{l}0.235 \\
\text { (ns) }\end{array}$ & $\begin{array}{l}0.342 \\
\text { (ns }\end{array}$ & $\begin{array}{l}0.371 \\
\text { (ns) }\end{array}$ & $\begin{array}{l}0.289 \\
\text { (ns) }\end{array}$ & $\begin{array}{l}0.505 \\
\text { (ns) }\end{array}$ & $\begin{array}{l}0.505 \\
\text { (ns) }\end{array}$ & $\begin{array}{l}0.24 \\
\text { (ns) }\end{array}$ & $\begin{array}{l}0.686 \\
\text { (ns) }\end{array}$ \\
\hline **Sign test & 2.214 & 3.015 & 2.667 & 2.667 & 1.581 & 1.809 & 1.768 & 2.267 \\
\hline${ }^{* *} p$-value & $\begin{array}{l}0.027 \\
(s)\end{array}$ & $\begin{array}{l}0.003 \\
(\mathrm{~s})\end{array}$ & $\begin{array}{l}0.008 \\
(s)\end{array}$ & $\begin{array}{l}0.008 \\
(\mathrm{~s})\end{array}$ & $\begin{array}{l}0.114 \\
\text { (ns) }\end{array}$ & $\begin{array}{l}0.070 \\
\text { (ns) }\end{array}$ & $\begin{array}{l}0.077 \\
\text { (ns) }\end{array}$ & $\begin{array}{l}0.023 \\
(\mathrm{~s})\end{array}$ \\
\hline
\end{tabular}

Abbreviations: (s) statistically significant, (ns) statistically non-significant, ${ }^{*}$ comparison between baseline and JROM after short-term ERT, ${ }^{* *}$ comparison between baseline and JROM after long-term ERT.

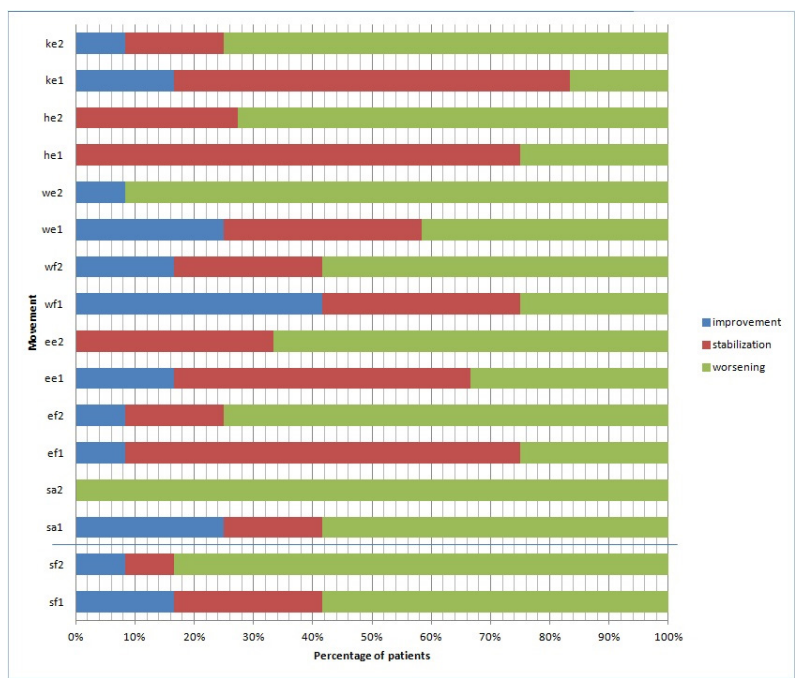

Figure 1. Efficacy of short- and long-term ERT on passive JROM of the upper and lower extremities in group 1.

Abbreviations: 1, short-term ERT; 2, long-term ERT; sf, shoulder flexion; sa, shoulder abduction; ef, elbow flexion; ee, elbow extension; wf, wrist flexion; we, wrist extension; he, hip extension; ke, knee extension.

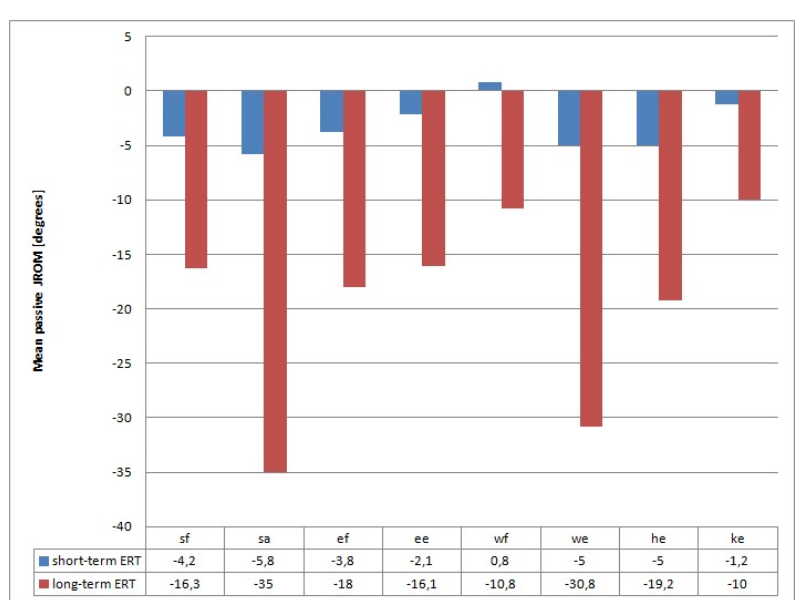

Figure 2. Mean passive JROM (degrees) for all patients from group 1 at baseline and after short-term (52 weeks) and longterm (mean 230 weeks) ERT.

Abbreviations: sf, shoulder flexion; sa, shoulder abduction; ef, elbow flexion; ee, elbow extension; wf, wrist flexion; we, wrist extension; he, hip extension; ke, knee extension. 
Table 3. Efficacy of short-term ERT on passive JROM of the upper and lower extremities in group 2.

JROM values (in degrees) for each patient were presented in one raw as following: at baseline, after short-term ERT. An increase in passive ROM of at least $10^{\circ}$ was considered an improvement and indicated by bold font.

\begin{tabular}{|c|c|c|c|c|c|c|c|c|}
\hline $\begin{array}{l}\text { Movement in } \\
\text { degrees } \\
\text { Passive ROM } \\
\text { (normal) }\end{array}$ & $\begin{array}{l}\text { Shoulder } \\
\text { flexion } \\
\left.()^{\circ}\right) \\
180\end{array}$ & $\begin{array}{l}\text { Shoulder } \\
\text { abduction } \\
\left({ }^{\circ}\right) \\
180\end{array}$ & $\begin{array}{l}\text { Elbow } \\
\text { flexion } \\
(\circ) \\
155\end{array}$ & $\begin{array}{l}\text { Elbow } \\
\text { extension } \\
\left({ }^{\circ}\right) \\
0\end{array}$ & $\begin{array}{l}\text { Wrist } \\
\text { flexion } \\
\left({ }^{\circ}\right) \\
90\end{array}$ & $\begin{array}{l}\text { Wrist } \\
\text { extension } \\
\left({ }^{\circ}\right) \\
80\end{array}$ & $\begin{array}{l}\text { Hip } \\
\text { extension } \\
\left({ }^{\circ}\right) \\
20\end{array}$ & $\begin{array}{l}\text { Knee } \\
\text { extension } \\
\left({ }^{\circ}\right) \\
0\end{array}$ \\
\hline \multicolumn{9}{|l|}{ Patient no } \\
\hline 13 & $130 / 140$ & $110 / 110$ & $150 / 140$ & $-30 /-40$ & $40 / 50$ & $10 / 20$ & $20 / 20$ & $0 / 0$ \\
\hline 14 & $130 / 120$ & $130 / 120$ & $150 / 150$ & $-35 /-45$ & $25 / 45$ & $20 / 30$ & $20 / 20$ & $0 / 0$ \\
\hline 15 & $90 / 90$ & $60 / 70$ & $150 / 120$ & $-40 /-50$ & $20 / 20$ & $0 / 0$ & $0 /-20$ & $-20 /-30$ \\
\hline 16 & $110 / 120$ & $100 / 100$ & $150 / 150$ & $-40 /-40$ & $80 / 70$ & $20 / 20$ & $20 / 0$ & $0 / 0$ \\
\hline Mean & $115.0 / 117.5$ & $100 / 100$ & $150 / 140$ & $-36.3 / 43.8$ & $41.3 / 46.3$ & $12.5 / 17.5$ & $15.0 / 15.0$ & $-5.0 /-7.5$ \\
\hline S.D. & $19.1 / 20.6$ & $29.4 / 21.6$ & $0.0 / 14.1$ & $4.8 / 4.8$ & $27.2 / 20.6$ & $9.6 / 12.6$ & $10.0 / 10.0$ & $10.0 / 15.0$ \\
\hline Sign test & 0.534 & -0.707 & 1.342 & 1.155 & 0.534 & 1.342 & - & - \\
\hline$p$-value & $\begin{array}{l}0.593 \\
\text { (ns) }\end{array}$ & $\begin{array}{l}0.479 \\
\text { (ns) }\end{array}$ & $\begin{array}{l}0.179 \\
\text { (ns) }\end{array}$ & $\begin{array}{l}0.248 \\
\text { (ns) }\end{array}$ & $\begin{array}{l}0.593 \\
\text { (ns) }\end{array}$ & $\begin{array}{l}0.179 \\
\text { (ns) }\end{array}$ & - & - \\
\hline
\end{tabular}

Abbreviations: (s) statistically significant, (ns) statistically non-significant.

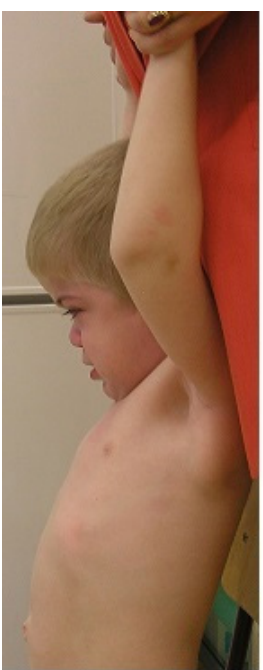

A

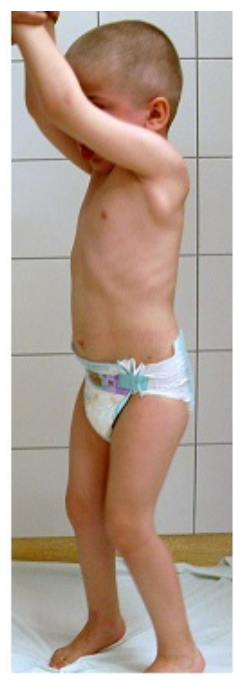

B

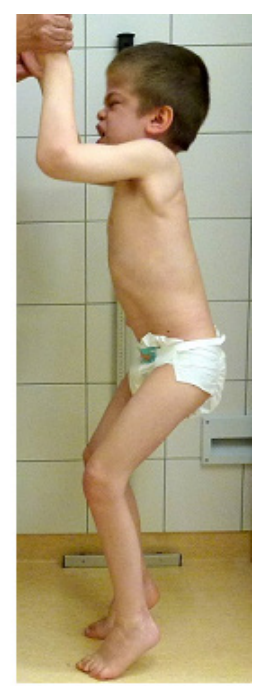

C
Figure 3. Clinical pictures of Patient 07 with neuronopathic (severe) phenotype at baseline (A), after 52 weeks of ERT (B), after 7 years of ERT $(C)$.

The wrist flexion improved in $2(16 \%$ vs. $42 \%$ after short-term ERT) patient while shoulder flexion and elbow extension in $1(8 \%$ vs. $8 \%$ after short-term ERT) patient (Table 2 and Fig. 1). There was no improvement in the shoulder abduction, elbow flexion and extension, hip and knee extension.

The passive JROM improvement between baseline and after both 52 weeks of ERT (short-term ERT) and 230 weeks (mean time of long-term ERT) was not statistically significant (Table 2).

The degree of restriction of passive JROM in the upper and lower extremities after short- and long-term ERT was presented in Fig. 2. A passive ROM of the shoulder abduction (Fig. 3), wrist extension and hip extension were the most restricted movements ( -35 , -30.8 and -19.2 degrees, respectively, after long-term ERT), while the wrist flexion was the least restricted.
Group 2 (attenuated phenotype, $n=4$ )

In group 2, a passive ROM of the shoulder flexion, wrist flexion and extension improved in $2(50 \%)$ patients, while shoulder abduction in $1(25 \%)$ of those patients (Table 3). There was no improvement in elbow flexion and extension, knee and hip extension.

\section{DISCUSSION}

Joint stiffness is a typical feature of MPS II patients, however studies on the mobility profile of MPS patients are scarce. In our previous study we described an early ROM impairment in children with MPS II (Marucha et al., 2012). Restrictions in shoulder joints were the earliest being observed already before the second year of life. Since ERT with idursulfase became available for MPS II patients, many studies reported its clinical efficacy (7-9). It is known that the response to ERT appears to depend on the severity of the condition of individuals and the age at which ERT begins (Tylki-Szymańska et al., 2012). One of our patients (Patient 01) started treatment before the onset of irreversible changes which allowed the slower progression of passive JROM.

There is little information about the clinical efficacy of ERT with idursulfase on the JROM of MPS II patients. Thus, we conducted the study aiming to assess the efficacy of ERT on the passive JROM of the upper and lower extremities in a cohort of 16 Polish MPS II patients, diagnosed and followed in our Institute. Our study presents one of the longest observation periods, reported in the literature, on the efficacy of ERT with idursulfase on the JROM in patients with MPS type II. We have observed no significant improvement in passive JROM of patients with both neuronopathic (severe) and attenuated forms of MPS II treated with ERT. Shoulder abduction, wrist extension and hip extension were the most restricted joint movements.

Our observations are similar to those reported in the literature. Lampe and others described the efficacy of long-term ( $\geq 2$ years continuously) ERT in a series of severe MPS II patients from five international centres (Lampe et al., 2014). An improvement in JROM was reported for $7 / 21$ patients $(33 \%)$, while $13 / 21$ patients $(62 \%)$ showed the stabilization of joint disease. Tomanin 
and others described the clinical efficacy of long-term (3.5 years) ERT in 27 Hunter patients (17 patients with severe form and 10 with attenuated form starting ERT between 1.6 and 27 years of age) (Tomanin et al., 2014). An improvement in JROM was reported in the upper extremity of $43 \%$ of patients starting ERT before 12 years of age and of $41 \%$ of patients older than 12 years. In our study, JROM was assessed after a longer period of ERT (mean 230 weeks) and the improvement was observed in a minor percentage of patients (16\% vs. $33 \%)$.

Parini and others reported the outcomes of $17 \mathrm{pa}-$ tients (including 11 with severe phenotype) treated in a single centre, while 16 of them were treated for a minimum of 5 years (Parini et al., 2015). The improvement in JROM was noted over the first two years of ERT for the shoulders, elbows, hips and knees. However, after 5 years of treatment it changed only for the right shoulder compared to baseline.

In the largest 2-year extension study of idursulfase treatment of 94 patients with Hunter syndrome, Muenzer and others observed clinically important improvements in JROM only for combined shoulder flexion/ extension and shoulder abduction; no improvement was seen for other joints (Muenzer et al., 2011). Our results are opposite to these observations, ROM of the shoulder abduction is one of the most restricted movements.

\section{CONCLUSIONS}

ERT with idursulfase is of low efficacy on correcting the passive range of motion of joints in patients with MPS type II.

\section{Authors' contribution}

JM designed the study, collected, and analysed clinical data, interpreted the results, wrote the manuscript. PL critically revised and approved the final manuscript. ATS critically revised and approved the final manuscript.

\section{Conflicts of interest}

The authors declare no conflict of interest.

\section{Data Availability Statement}

All data generated or analyzed during this study are included in this published article.

\section{REFERENCES}

Beck M, Muenzer J, Scarpa M (2010). Evaluation of disease severity in mucopolysaccharidoses. J Pediatr Rehabil Med 3: 39-46. https://doi. org/10.3233/PRM-2010-0100

Gerhardt JJ, Rondinelli RD (2001). Goniometric techniques for rangeof-motion assessment. Phys Med Rehabil Clin N Am 12: 507-527. https://doi.org/10.1016/S1047-9651(18)30047-0

Hinek A, Wilson SE (2000). Impaired elastogenesis in Hurler disease: dermatan sulfate accumulation linked to deficiency in elastin-binding protein and elastic fiber assembly. Am I Pathol 156: 925-938. https://doi.org/10.1016/S0002-9440(10)64961-9

Lampe C, Bosserhoff AK, Burton BK, Giugliani R, de Souza CF, Bittar C, Muschol N, Olson R, Mendelsohn NJ (2014). Long-term experience with enzyme replacement therapy (ERT) in MPS II patients with a severe phenotype: an international case series. I Inherit Metab Dis 37: 823-829. https://doi.org/10.1007/s10545-014-9686-7

Marucha J, Jurecka A, Syczewska M, Różdżyńska-Swiątkowska A, Tylki-Szymańska A (2012). Restricted joint range of motion in patients with MPS II: correlation with height, age and functional status. Acta Paediatr 101: e183-e188. https://doi.org/10.1111/j.16512227.2011.02522.x

Muenzer J, Wraith JE, Beck M, Giugliani R, Harmatz P, Eng CM, Vellodi A, Martin R, Ramaswami U, Gucsavas-Calikoglu M, Vijayaraghavan S, Wendt S, Puga AC, Ulbrich B, Shinawi M, Cleary M, Piper D, Conway AM, Kimura A (2006). A phase II/III clinical study of enzyme replacement therapy with idursulfase in mucopolysaccharidosis II (Hunter syndrome). Genet Med 8: 465-473. https:// doi.org/10.1097/01.gim.0000232477.37660.fb

Muenzer J, Gucsavas-Calikoglu M, McCandless SE, Schuetz TJ, Kimura A (2007). A phase I/II clinical trial of enzyme replacement therapy in mucopolysaccharidosis II (Hunter syndrome). Mol Genet Metab 90: 329-337. https://doi.org/10.1016/j.ymgme.2006.09.001

Muenzer J, Beck M, Eng CM, Giugliani R, Harmatz P, Martin R, Ramaswami U, Vellodi A, Wraith JE, Cleary M, Gucsavas-Calikoglu M, Puga AC, Shinawi M, Ulbrich B, Vijayaraghavan S, Wendt S, Conway AM, Rossi A, Whiteman DA, Kimura A (2011). Longterm, open-labeled extension study of idursulfase in the treatment of Hunter syndrome. Genet Med 13: 95-101. https://doi.org/10.1097/ GIM.0b013e3181fea459

Parini R, Rigoldi M, Tedesco L, Boffi L, Brambilla A, Bertoletti S, Boncimino A, Del Longo A, De Lorenzo P, Gaini R, Gallone D, Gasperini S, Giussani C, Grimaldi M, Grioni D, Meregalli P, Messinesi G, Nichelli F, Romagnoli M, Russo P, Sganzerla E, Valsecchi G, Biondi A (2015). Enzymatic replacement therapy for Hunter disease: Up to 9 years experience with 17 patients. Mol Genet Metab Rep 3: 65-74. https://doi.org/10.1016/j.ymgmr.2015.03.011

Scarpa M, Almássy Z, Beck M, Bodamer O, Bruce IA, De Meirleir L, Guffon N, Guillén-Navarro E, Hensman P, Jones S, Kamin W, Kampmann C, Lampe C, Lavery CA, Teles EL, Link B, Lund AM, Malm G, Pitz S, Rothera M, Stewart C, Tylki-Szymańska A, van der Ploeg A, Walker R, Zeman J, Wraith JE; Hunter Syndrome European Expert Council (2011). Mucopolysaccharidosis type II: European recommendations for the diagnosis and multidisciplinary management of a rare disease. Orphanet J Rare Dis 6: 72. https://doi.org/ 10.1186/1750-1172-6-72.

Shapiro EG, Rudser K, Ahmed A, Steiner RD, Delaney KA, Yund B, King K, Kunin-Batson A, Eisengart J, Whitley CB (2016). A longitudinal study of emotional adjustment, quality of life and adaptive function in attenuated MPS II. Mol Genet Metab Rep 7: 32-39. https://doi.org/10.1016/j.ymgmr.2016.03.005

Simonaro CM, D'Angelo M, He X, Eliyahu E, Shtraizent N, Haskins ME, Schuchman EH (2008). Mechanism of glycosaminoglycanmediated bone and joint disease: implications for the mucopolysaccharidoses and other connective tissue diseases. Am J Pathol 172: 112-122. https://doi.org/10.2353/aipath.2008.070564

Tomanin R, Zanetti A, D’Avanzo F, Rampazzo A, Gasparotto N, Parini R, Pascarella A, Concolino D, Procopio E, Fiumara A, Borgo A, Frigo AC, Scarpa M (2014). Clinical efficacy of enzyme replacement therapy in paediatric Hunter patients, an independent study of 3.5 years. Orphanet J Rare Dis 9: 129. https://doi.org/10.1186/s13023014-0129-1

Tylki-Szymańska A (2014). Mucopolysaccharidosis type II, Hunter's syndrome. Pediatr Endocrinol Rev 12 (Suppl 1:) 107-113. PMID: 25345092

Tylki-Szymanska A, Jurecka A, Zuber Z, Rozdzynska A, Marucha J, Czartoryska B (2012). Enzyme replacement therapy for mucopolysaccharidosis II from 3 months of age: a 3-year follow-up. Acta Paediatr 101: e42-e47. https://doi.org/10.1111/j.16512227.2011.02385.x 